\title{
Typology of Dairy Production Systems Based on Management Strategies in Paraná State, Brazil
}

\author{
R. C. M. Tramontini ${ }^{a}$, F. I. Bánkuti ${ }^{a}$, M. S. S. Pozza ${ }^{a}$, E. M. Massuda ${ }^{\text {, }}$ J. C. Damasceno ${ }^{a}$, A. M. Dias ${ }^{c}$, C. C. \\ B. F. Ítavoc , L. C. V. Ítavoc ${ }^{c}$ \& G. T. Santos ${ }^{\mathrm{d}, *}$ \\ aPrograma de Pós-Graduação em Zootecnia (PPZ), Universidade Estadual de Maringá \\ bPrograma de Pós-Graduação em Gestão do Conhecimento das Organizações, Universidade Cesumar (Unicesumar) \\ 'Programa de Pós-Graduação em Ciência Animal (PPGCA), Universidade Federal do Mato Grosso do Sul \\ 'Programa de Pós-Graduação em Zootecnia (PPZ), Universidade Estadual de Maringá, Programa de Pós-Graduação em \\ Ciência Animal (PPGCA), Universidade Federal do Mato Grosso do Sul \\ Av. Colombo, 5790, Maringá Paraná. Av. Filinto Muller, 2443, Campo Grande, Brazil \\ "Corresponding author: gtsantos50@gmail.com \\ (Received 23-06-2020; Revised 16-09-2020; Accepted 28-09-2020)
}

\begin{abstract}
This study aimed to analyze the typology of dairy production systems in Paraná State using management characteristics related to nutrition, milking, and technical aspects. We applied, in loco, 105 surveys in dairy production systems - DPS, located in Paraná State, Brazil. Variables related to farm structure, farmer social characteristics, and management practices applied in dairy systems, were collected. Exploratory Factor analysis (EFA) was used and resulted in three management factors, i.e., F1 (Nutrition Management), F2 (Technical Management), and F3 (Milking Management). Using factorial scores, cluster analysis was employed to identify homogeneous groups of dairy production systems. The dairy production systems in $\mathrm{G} 2(\mathrm{~N}=84 \mathrm{DPS})$ was characterized by prioritizing nutritional management (F1), which was the opposite result presented by G1 (N=21 DPS). The structural features and social characteristics of G1 and G2 were compared (T-test). The results indicated a great heterogeneity for the structural and productive characteristics of the analyzed dairy systems and socioeconomic characteristics of their managers. Results also indicate that producers with less structure and scale of production (Group 1), need more technical guidance in production system management. For producers with larger structures and scales of production (Group 2), continuous improvement investments are suggested in the three factors analyzed in this work - nutritional, technical, and milking. Such actions may maintain or increase the production and productivity results in these dairy systems. It is concluded that aspects related to nutritional management are the ones that mark the biggest difference between the cases analyzed, followed respectively by factors of technical management and milking management. Typology of dairy systems that adopt greater attention to nutritional management practices is characterized by a greater production structure and greater productivity when compared to a typology of dairy systems that prioritize actions of technical system management and milking management.
\end{abstract}

Keywords: dairy farming; management; productivity

\section{INTRODUCTION}

Brazilian milk production has an important economic position, reaching 33.8 billion liters, placing the country as the third largest cow's milk producer in the world (FAO, 2019). Milk production in Brazil also serves as an important social function. It was estimated that in 2017, 1.1 million Brazilian farms were engaged in milk production, $81 \%$ of which were family-based and generated income for over four million people (IBGE, 2018). In addition, milk production occupies areas where other agricultural crops would be less appropriated, thus contributing to the settlement of men in the field (Bánkuti \& Caldas, 2018).

The Paraná State is an important milk producer in Brazil. In 2017, they produced 3.2 billion liters of milk,
9.5\% of national production (IBGE, 2018). As in Brazil, Paraná's milk production also has an important social function. Milk production activity in Paraná employs, approximately 261,189 direct jobs and 87,063 milk producers (IBGE, 2018).

Despite the large representation of dairy production systems (DPS) in Brazil and Paraná State, there are many obstacles that need to be solved (Brito et al., 2015). Among these is the low quality of milk and the small volume of production per farm are the main obstacles (Defante et al., 2019; Bánkuti et al., 2020). Those results are influenced by access to technical assistance, nutritional management, good milking practices, farmer's attitudes, and farm characteristics (Beber et al., 2019).

The degree of techniques applied in DPS and the way of milking processing is used directly related to 
milk quality (Defante et al., 2019). Furthermore, the management practices adopted in the DPS, such as those related to nutritional aspects and pasture as well as herd management, are strictly related to DPS success (Llanos et al., 2018; Notte et al., 2020).

Dairy production systems in Brazil are characterized by the expressive heterogeneity regarding the production process (Ponciano et al., 2010; Vanh Der Ploeg, 2010). Therefore, milk production in Brazil is complex by nature; it depends on a large number of farmers with low-production scales and diversity strategies, imposing challenges to the development of production systems (Bodenmüller Filho et al., 2010). Considering the heterogeneity of the dairy systems, regional studies must be carried out, so that action proposals can be better oriented.

Although some studies have already addressed questions about decision making and management of Paraná's milk systems, most of these studies did not consider nutritional management strategies, being more focused on issues related to cost management, milk quality, and socio-environmental adequacy, among others (Zimpel et al., 2017; Defante et al., 2019; Bánkuti et al., 2020; Casali et al., 2020). In this sense, this study fulfills a literature gap by analyzing DPS typology in Paraná State using management characteristics related to nutrition, milking, and technical aspects.

\section{METHODS}

This study was conducted in nine municipalities in the metropolitan region of Umuarama, located in the Northwest of Paraná State. This region is one of the most important livestock-raising regions in Paraná State, composed of 2.3 million hectares of pastures, covering $72 \%$ of the region. It holds $36.5 \%$ of the cattle herd of Paraná
State and produces around 180 million liters of milk (IBGE, 2015).

We applied, in loco, 105 surveys with dairy farmers (Foddy, 1994; Brito et al., 2015). The surveys were approved by the Ethics Committee (CAAE) of the State University of Maringá (No. 78877117.5.0000.0104). The selection of dairy farmers was conducted by the snowball sampling method (Guptill, 2009). Using this procedure, we collected three sets of variables. The first one related to DPS structural and productive characteristics; the second variable related to farmer's socioeconomics characteristics, and the third variable related to management applied in the production system, as well as nutritional, technical, and milking characteristics (Table 1 and Table 2). In addition, qualitative information was observed during the survey's application.

Data were treated and statistically analyzed through the Statistical Package for Social Sciences-SPSS $₫$, version 18 (IBM, 2009). For the first two sets of variablesstructural, productive, and socioeconomic variables, we performed a descriptive analysis to characterize the DPS and farmers. For a second time, variables related to management practices in DPS were used to define the factors/ indicators of typology of dairy systems. For that objective, we performed exploratory factor analysis (EFA).

The EFA model was applied as follows (Equation 1):

$$
\begin{aligned}
& X_{1}=a_{11} \times F_{1}+a_{12} \times F_{2}+\cdots+a_{1 \mathrm{~m}} \times F_{\mathrm{m}}+e_{p} \\
& X_{2}=a_{21} \times F_{1}+a_{21} \times F_{2}+\cdots+a_{2 \mathrm{~m}} \times F_{\mathrm{m}}+e_{p} \\
& \vdots \\
& X_{p}=a_{p 1} \times F_{1}+a_{p 1} \times F_{2}+\cdots+a_{p \mathrm{~m}} \times F_{\mathrm{m}}+e_{p}
\end{aligned}
$$

where $X_{p}$ represents the $p$-th score of the standardized

\begin{tabular}{|c|c|}
\hline Variables & Variable type \\
\hline Educational level & Metric \\
\hline Farmer's age (years) & Metric \\
\hline Years in dairy production (years) & Metric \\
\hline Number of works in dairy activity & Metric \\
\hline Total area of property (ha) & Metric \\
\hline Total area designed for milk production (ha) & Metric \\
\hline Total area designed for other activities (ha) & Metric \\
\hline Total number of cows (head) & Metric \\
\hline Number of cows in milk (head) & Metric \\
\hline Total milk production (liters/day) & Metric \\
\hline Milk production per cow (liters of milk/cow /day) & Metric \\
\hline Total pasture area (ha) & Metric \\
\hline Type of pasture & Ordinal (1- conventional; 2- conventional/rotational; 3- rotational; 4- irrigated) \\
\hline Milking system & Ordinal (1- manual milking; 2 -bucket milking; 3- pipe line milking) \\
\hline Type of milk cooler & Ordinal (1-immersion tanks; 2-community bulk tanks; 3-bulk coolers) \\
\hline Livelihood place & Nominal (1- rural area; 2- urban area) \\
\hline Labor type & Nominal (1-family labor; 2- hired labor; 3- hired and family labor) \\
\hline Cattle pattern & Nominal (1-purebreed; 2- crossbreed) \\
\hline Predominant breed & $\begin{array}{l}\text { Nominal (1-Sem raça definida; 2- girolando; 3- Holstein; 4- Jersey; 5-Gir; 6- } \\
\text { Holstein/Jersey; 7- Holstein/Gir/ 8- Girolando/ Holstein) }\end{array}$ \\
\hline
\end{tabular}
variable $(p=1,2, \ldots \mathrm{m}), F_{\mathrm{m}}$ is the extracted factor, $a_{p \mathrm{~m}}$ is the factor loading, and $e_{p}$ is the error.

Table 1. Structural, productive, and socioeconomic variables applied in descriptive analysis 
Table 2. Dairy production system management variables applied in exploratory factor analysis

\begin{tabular}{|c|c|}
\hline Variables & Variable type \\
\hline Number of milking (milking/day) & Ordinal (1- one milking; 2- two milking) \\
\hline Good hygienic practices in milking process & Ordinal (1- there is no good practice; 2 - good practices are carried out) \\
\hline Mastitis control & Ordinal (1- there is no mastitis control; 2- there is a mastitis control) \\
\hline Veterinary assistance & Ordinal (1- there is no veterinary assistance; 2 - there is a veterinary assistance) \\
\hline Livestock herd control & Ordinal (1- there is no zootechnical control; 2 - This is a zootechnical control) \\
\hline Selection of heifer to replace females & Ordinal (1- is not accomplished; 2- is accomplished) \\
\hline Selling of surplus cows & $\begin{array}{l}\text { Ordinal (1- does not provide; } 2 \text { - provides the same amount for all animals; } 3 \text { - } \\
\text { provides quantities based on the production of each animal) }\end{array}$ \\
\hline Feed type during weaning and the heifer phase & $\begin{array}{l}\text { Ordinal (1- milk and pasture; } 2 \text { - milk, roughage in the trough; } 3-\text { milk, bulky in } \\
\text { the trough and concentrated; } 4 \text { - milk, concentrate and hay) }\end{array}$ \\
\hline Feed type to heifers until insemination time & $\begin{array}{l}\text { Ordinal (1- pasture; } 2 \text { - pasture and concentrate; } 3 \text { - bulky and concentrated; } \\
4 \text {-silage and concentrate) }\end{array}$ \\
\hline Feed type from pregnancy to pre-calving & $\begin{array}{l}\text { Ordinal (1- pasture; } 2 \text { - pasture and concentrate; } 3 \text { - bulky in the trough and } \\
\text { concentrated; } 4 \text { - silage and concentrate) }\end{array}$ \\
\hline Type of heifers feeding: pre-calving to calving & $\begin{array}{l}\text { Ordinal (1- pasture; } 2 \text { - pasture and concentrate; } 3 \text { - bulky in the trough and } \\
\text { concentrated; } 4 \text { - silage and concentrate }\end{array}$ \\
\hline Type of female feeding during pre-calving & $\begin{array}{l}\text { Ordinal (1- pasture; 2- pasture and concentrate; } 3 \text { - roughage in the trough and } \\
\text { concentrated; } 4 \text { - silage and concentrate }\end{array}$ \\
\hline Type of feed in summer time & $\begin{array}{l}\text { Ordinal (1-pasture; } 2 \text {-pasture and concentrate; } 3 \text { - pasture, roughage in the } \\
\text { trough, and concentrate; } 4 \text { - pasture, silage, and concentrate) }\end{array}$ \\
\hline Type of concentrate to dairy cows & $\begin{array}{l}\text { Ordinal (1- don't use; 2- equal for all cows; } 3 \text { - specific concentrate for cows in } \\
\text { production) }\end{array}$ \\
\hline
\end{tabular}

Factor scores for each dairy farm were estimated by multiplying standardized variables by the coefficient of the corresponding factor score (Equation 2):

$$
\begin{aligned}
& F_{1}=d_{11} \times X_{1}+d_{12} \times X_{2}+\cdots+d_{1 j} \times X_{j p} \\
& F_{2}=d_{21} \times X_{1}+d_{21} \times X_{2}+\cdots+d_{2 j} \times X_{j p} \\
& \vdots \\
& F_{j}=d_{j 1} \times X_{1}+d_{j 1} \times X_{2}+\cdots+d_{j p} \times X_{j p}
\end{aligned}
$$$$
\text { ! }
$$

where $F_{j}$ is the $j$-th factor extracted, $d_{j p}$ is the factor score coefficient, and $p$ is the number of variables (Hair Jr. et al., 2009).

For EFA, the extraction method is defined as the common factor analysis with Varimax rotation type, standardization of Kaiser Meyer Olkin (KMO), and the Bartlett test of sphericity (Hair Jr. et al., 2009). Variables with low and medium load factor (less than $|0.5|$ ) were removed (Hair Jr. et al., 2009). To select the number of factors, the Kaiser criterion was used, which is based on the number of eigenvalues greater than 1.0 (Fávero et al., 2009; Hair Jr. et al., 2009).

As a next step, using the agglomerative cluster analysis method, score factors were used as input variables to define homogeneous groups of DPS (Barnes \& Toma, 2012; Mattos \& Santana, 2014; Rivas et al., 2015; Bánkuti et al., 2020). Hierarchical cluster analysis is an interdependence technique that results in groups of similar internal cases that are different from cases aggregated in other groups (Hair Jr. et al., 2009). Euclidean distance measure and the complete linkage method (Equation 3) were used:

$$
d[k,(i j)]=\max [d(k, i), d(k, j)]
$$

This agglomerative algorithm calculates the shortest distance between the two closest elements $i$ and $j$ using the distance matrix $d_{i j}$.

After generating the groups, we performed mean tests (Student's t-test) to compare the typology of dairy production systems in each group (Brito et al., 2015).

It is sought from studies of typology to assist the analysis of complex realities and to order objects that, although different, may present a set of similarities. From the typology studies, the analyzed systems can be compared with each other and then divided into groups according to their similarities and particularities (Kostrowicki, 1977). Typology studies can also support the definition of public policies and private strategies in the direction of improving production conditions in agricultural systems. Typology studies have been constantly employed in the analysis of agricultural systems (Gelasakis et al., 2017; Bánkuti \& Caldas, 2018; Wong et al., 2020).

\section{RESULTS}

\section{Characterization of Dairy Systems and Their Managers}

Regarding the social and economic characteristics findings in the 105 dairy production systems, most farmers presented an elementary/middle school education $(47.7 \%)$, followed by high school $(42.9 \%)$, and college (University graduates) $(9.5 \%)$. Most of the farmers, $76.2 \%$, were living in rural areas. They were, on average, 48 years old and had been working as dairy farmers for 17 years.

Family labor $(75.2 \%)$ predominated in the DPS, followed by hired $(21 \%)$, and hired and family (3.8\%). On 
average, two people were involved in dairy farming. As regards to structural characteristics, the properties had, on average, a total area of 26.7 ha. A total of 18.2 ha was for milk production, of which 10.7 ha were for pasture production. The remaining area (7.5 ha) was used for other agriculture and livestock activities. In these dairy systems, the herd was formed on average by 26 cows. Among these, 20 cows were in lactation, producing an average of 284 liters of milk per day in each production system.

Crossbred herds were predominant in the DPS (52.4\%), with a predominance of Holsteins. The mean number of cows in the herds was 26 heads (73\% represented by cows in milk).

As regards milking, $76.2 \%$ of the properties used mechanical milking (bucket milking). The other properties used manual milking $(13.3 \%)$ and pipeline milking (10.5\%). The milk was stored in bulk coolers on $88.6 \%$ of the properties, with $23.8 \%$ of this total stored in community bulk tanks and $11.4 \%$ in immersion tanks.

In relation to DPS surface management, rotational grazing prevailed in $37.1 \%$ of the systems, followed by conventional $(35.2 \%)$, conventional/rotational $(24.8 \%)$, and irrigated $(2.9 \%)$.

\section{Definition of Factors of Typology of Dairy Systems}

Exploratory factor analysis resulted in four factors with eigenvalues above 1.0. However, only three factors were chosen because they had attracted a significant proportion $(60.5 \%)$ of the total variance (Hair Jr. et al., 2009). The first factor (F1) represented $32.4 \%$ of the explained variance and, therefore, the best factor explaining the variance between the DPS analyzed; the second factor (F2), in order of contribution to the explained variance, represented $18.6 \%$, while the third factor (F3) represented $9.5 \%$ (Table 3 ).

To define the forming variables of each factor, the factor loadings above $|0.5|$ were considered. Variables with eigenvalues less than 0.5 are those that have a low correlation between the other variables that define each factor (Hair Jr. et al., 2009). In the present study, the "Selling of surplus cows" variable had to be disregarded (Table 4).

Factor 1 was defined by variables related to the nutritional management of the dairy herd. Therefore, it was called "Nutritional Management." Factor 2 was defined by variables that indicate actions of technical management of the production system. Thus, it was called "Technical Management." And Factor 3, was defined by milking management variables, being called "Milking Management" (Table 5).

\section{Comparison of Typology Factors Between Groups of Dairy Systems}

Using F1, F2, and F3 score factors, two groups were generated by cluster analysis. Group 1 (G1) comprised 84 DPS, representing $80 \%$ of the total DPS. Group 2 (G2) comprised 21 DPS, representing 21\% of

Table 3. Factor loadings and variances

\begin{tabular}{cccc}
\hline Factor & Factor loadings & Explained variance $(\%)$ & Total variance $(\%)$ \\
\hline F1 & 4.54 & 32.48 & 32.48 \\
F2 & 2.60 & 18.63 & 51.11 \\
F3 & 1.32 & 9.47 & 60.58 \\
F4 & 1.15 & 8.27 & 68.86 \\
\hline
\end{tabular}

Note: F1= Factor 1; F2= Factor 2; F3=Factor 3; F4=Factor 4.

Table 4. Factor loadings and composition of the factors extracted in the analysis

\begin{tabular}{|c|c|c|c|}
\hline \multirow{2}{*}{ Management variables } & \multicolumn{3}{|c|}{ Variables' loadings in each factor } \\
\hline & F1 & F2 & F3 \\
\hline Feed type during weaning and the heifer phase & 0.850 & 0.291 & 0.060 \\
\hline Feed type to heifers until insemination time & 0.853 & 0.280 & 0.077 \\
\hline Feed type from pregnancy to pre-calving & 0.882 & 0.180 & 0.057 \\
\hline Type of heifers feeding: pre-calving to calving & 0.847 & 0.086 & 0.003 \\
\hline Type of feed in summertime & 0.764 & 0.252 & 0.024 \\
\hline Good hygienic practices in milking process & 0.234 & 0.639 & 0.009 \\
\hline Veterinary assistance & 0.029 & 0.742 & 0.135 \\
\hline Livestock herd control & 0.099 & 0.807 & 0.169 \\
\hline Selection of heifer to replace females & 0.014 & 0.583 & 0.209 \\
\hline Type of female feeding during pre-calving & 0.336 & 0.747 & 0.050 \\
\hline Type of concentrate to dairy cows & 0.260 & 0.557 & 0.425 \\
\hline Number of milking (milking/day) & 0.067 & 0.172 & 0.789 \\
\hline Mastitis control & 0.016 & 0.044 & 0.746 \\
\hline Selling of surplus cows & 0.146 & 0.226 & 0.151 \\
\hline
\end{tabular}

Note: The variable "selling of surplus cows was discarded by presenting low loading factorial contribution in factors definition. 
Table 5. Mean scores factorial values for each DPS group

\begin{tabular}{|c|c|c|c|c|}
\hline Factors & Groups & $\mathrm{N}$ & Mean & Standard deviation \\
\hline \multirow[t]{2}{*}{ Nutritional management (F1) } & G1 & 84 & $-0.44^{\mathrm{B}}$ & 0.40 \\
\hline & $\mathrm{G} 2$ & 21 & $1.78^{\mathrm{A}}$ & 0.56 \\
\hline \multirow[t]{2}{*}{ Technical management (F2) } & G1 & 84 & $0.05^{\mathrm{a}}$ & 1.06 \\
\hline & $\mathrm{G} 2$ & 21 & $-0.20^{b}$ & 0.68 \\
\hline \multirow[t]{2}{*}{ Milking management (F3) } & G1 & 84 & $0.01^{\mathrm{a}}$ & 1.06 \\
\hline & G2 & 21 & $-0.06^{\mathrm{b}}$ & 0.68 \\
\hline
\end{tabular}

Note: ${ }^{a b}$ means in the same column with different superscripts differ significantly $(\mathrm{p} \leq 0.05) ;{ }^{\mathrm{A}, \mathrm{B}}$ means in the same column with different superscripts differ significantly $(\mathrm{p} \leq 0.01)$.

Table 6. Structural variables analysis between the groups

\begin{tabular}{lccc}
\hline Structural variables & $\mathrm{G} 1$ & $\mathrm{G} 2$ & Standard error \\
\hline Total area of the property (ha) & $10.68^{\mathrm{B}}$ & $17.83^{\mathrm{A}}$ & 4.54 \\
Area used for milk production (ha) & $6.41^{\mathrm{B}}$ & $14.78^{\mathrm{A}}$ & 3.23 \\
Total number of cows in the herd (head) & $21.64^{\mathrm{B}}$ & $42.90^{\mathrm{A}}$ & 5.23 \\
Total number of dairy cows (head) & $16.29^{\mathrm{B}}$ & $31.48^{\mathrm{A}}$ & 4.32 \\
Percentage of dairy cows (\%) & $59.20^{\mathrm{a}}$ & $66.52^{\mathrm{a}}$ & 6.90 \\
Total milk production/day (L/day) & $199.31^{\mathrm{B}}$ & $620.95^{\mathrm{A}}$ & 102.24 \\
Mean cow production/day (L/cow/day) & $11.80^{\mathrm{b}}$ & $16.97^{\mathrm{a}}$ & 0.97 \\
Price received for the milk (R $\$$ L) & $0.95^{\mathrm{a}}$ & $1.05^{\mathrm{a}}$ & 0.16 \\
Total pasture area (ha) & $4.36^{\mathrm{b}}$ & $9.24^{\mathrm{a}}$ & 1.99 \\
Area cultivated with Napier grass (ha) & $0.22^{\mathrm{B}}$ & $0.73^{\mathrm{A}}$ & 0.17 \\
Area cultivated with sugarcane (ha) & $0.20^{\mathrm{b}}$ & $0.08^{\mathrm{a}}$ & 0.80 \\
Area cultivated with corn/sorghum (ha) & $1.24^{\mathrm{B}}$ & $6.62^{\mathrm{A}}$ & 1.47 \\
\hline
\end{tabular}

Note: ${ }^{a b}$ means in the same row with different superscripts differ significantly $(\mathrm{p} \leq 0.05) ;{ }^{\mathrm{A}, \mathrm{B}}$ means in the same row with different superscripts differ significantly $(\mathrm{p} \leq 0.01)$.

the total DPS. After that, G1 and G2 were compared by their mean factorial scores. Group 1 achieved the best results in "Technical Management" (F2) and "Milking Management" (F3) when compared with G2. On the other hand, G2 achieved the best results in "Nutritional Management" (F1) (Table 5).

Statistical analyses showed that, in addition to nutritional management of the herd in the DPS, G2 differed from G1 in the structural variables, such as, area of the property (ha), area used for milk production (ha), total number of cows in the herd (head), total number of dairy cows (head), total milk production (L/day), mean cow production (L/cow/day), total pasture area (ha), area cultivated with sugarcane (ha), and area cultivated with corn/sorghum (ha) (Table 6).

\section{DISCUSSION}

The characterization of the 105 dairy systems and their managers indicated that the sample analyzed was formed predominantly by milk producers with a low level of formal education-only $9.5 \%$ had a college degree. In addition, the sample analyzed was formed by producers with a median age of 48 years and with a good experience in the livestock activity -17 years. These results are similar to a set of other studies carried out with milk producers in the state of Paraná (Zimpel et al., 2017; Bánkuti et al., 2020).

The level of education, the age of the rural producer, and the accumulated experience in the dairy activity can be indicatives of the easier interpretation of production standards and techniques in the dairy systems. Older and less educated producers may have more difficulties in managing the production system and greater path dependence (Zimpel et al., 2017).

Among the producers analyzed, $75.2 \%$ were family members. This participation is very close to that estimated for the state of Paraná, 80\% (IBGE, 2018). Milk production in family systems, not only in the state of Paraná, fulfills an important economic and social function, being able to generate monthly incomes and to employ large numbers of people and occupy areas where other agricultural activities are less favorable, either due to conditions topography and soil quality (Bánkuti, \& Caldas, 2018). Unlike annual crops, in which the income from productive activity occurs once or twice a year, milk production allows monthly remuneration to the rural producer and his family, thus facilitating the planning of the use of financial resources and reducing the risk of losses in the face of economic instability, a situation that is very common in developing countries like Brazil.

Regarding the structural characteristics of the 105 dairy systems, it was found that they are of small and medium scale of production since they presented herds formed on average by 20 lactating cows and average production of $283 \mathrm{~L}$ of milk per day. This characterization is consistent with those reported in other studies conducted in the state of Paraná (Defante et al., 2019; Bánkuti et al., 2020). 
Regarding the milking and milk storage technology, the systems analyzed showed good results. The vast majority, $76.2 \%$ of the analyzed producers, used mechanical milking systems, and $88.7 \%$ stored the milk in refrigeration tanks (expansion tanks and immersion tanks). Even though Brazilian legislation requires that milk is stored in expansion-type refrigeration tanks (Brazil, 2018), some rural producers still use alternative systems, for example, immersing gallons of milk in chilled water.

Considering the variables that generated the typology indicators, it was found that the characteristics related to Nutritional Management - F1 were those that most marked the differences between the cases analyzed - those with the highest accumulated variance (Table 3). This result indicates that the nutritional factors are the most important to differentiate the milk systems analyzed in this work.

The nutrition of the herd represents an important aspect in DPS (Roche, 2006; Walsh et al., 2011). The proper nutrition for lactating cows, in addition to higher milk production, is also responsible for a significant portion of production costs, labor, and land use in DPS. Any action to balance supply and demand for feed has a great weight in DPS results (Llanos et al., 2018; Koerich et al., 2019).

The second set of variables of the typology that most marked differences between the cases analyzed were those related to the Technical Management - F2 aspects. Therefore, after the characteristics of nutritional management, technical management is the most important to differentiate the analyzed milk systems (Table 3).

Better production practices applied in DPS can result in better results for farmers. Good milking hygiene practices lead to milk with higher quality and hence better prices received by the farmers (Defante et al., 2019). Besides that, productivity gains can arise when farmers use technology inputs, such as genetic improvement of the herd, feed, and animal health.

Factor 3 (F3 - Milking Management) was the one that presented the lowest explained variance among the analyzed cases. Therefore, the typology factor represents the management differences between the analyzed milk systems less intensely. This factor is less important, respectively than the factors of nutritional management (F1) and technical management (F2) (Table 3).

The milk process management is associated with milk quality and bacterial count and, for that, with the price received by the farmer (Millogo et al., 2010). The milking intervals also represent an important practice in DPS, especially considering the possibility of saving time without losses in production and milk quality (Marnet et al., 2008).

The comparative analysis between the groups of dairy systems (G1 and G2) and the typology factors (F1, F2, and F3) indicate that Group 1 producers focus their actions on the Technical Management and Milking Management strategies. This condition leaves Nutritional Management actions in the background (Table 5). In addition, the results indicated that Group 1 producers had a lower production structure - among these, those related to the area of the property and the area for feed production, herd size, and variables related to productivity in the dairy production system (Table 6). Therefore, the dairy production systems of Group 1 have a structural and productive characteristic of a smaller scale when compared to the characteristics of dairy systems in Group 2. Considering the lower results for the indicators - total milk production (L/day); mean cow production/day (L/cow/day), and price received for the milk (R \$/L), obtained by G1 (Table 6), it is suggested that the DPS located in G1 needs to improve nutritional management, to balance the supply of and demand for feed, represented by the herd size and production potential.

Conversely, Group 2 producers direct their actions towards Nutritional Management issues (Table 5). The importance given by G2 to nutritional management (Table 5) is possible because of the large area reserved for milk production and the way the forage production surface area is managed (Table 6). The results also indicate that Group 2 producers have a larger production scale and better productivity indicators (Table 6). Thus, it can be inferred that aspects related to the nutritional management of animals - those defined in F3-are extremely important for the generation of positive results in dairy systems.

Other works have already studied the management practices in dairy systems in Paraná. Defante et al. (2019) found a positive relationship between milking hygiene practices and structural and productivity variables in dairy systems in Paraná. Zimpel et al. (2017) also found dairy systems that more frequently adopted management tools tended to have a greater structure of production and productivity compared to systems that had not adopted management tools. In this work, factors related to the system management practices (F2) and milking management (F3) when compared with the nutritional management (F1) of the herd, indicated that the first two were less important compared to nutritional management (F1). Thus, this work makes an important contribution by identifying which factors related to the nutrition of the herd can be even more important in determining productive results and productivity in the dairy systems of Paraná. Because of these results, it is proposed as the main strategy for the dairy systems of group 1 to pay greater attention to the management of nutritional aspects of the dairy herd. Considering that these are producers with a small structure and scale of production, collective actions via producer cooperatives should be considered. According to Brito et al. (2015) and Casali et al. (2020), milk producers in the state of Paraná have achieved a set of competitive advantages and reduced information asymmetries when participating in collective arrangements. In a complementary way, it is suggested that public policies aimed at technical assistance and training of rural producers to deal with issues of nutritional management of the herd should be considered. For group 2 producers, constant investment in improvements to the management systems already used is suggested. It is also suggested that, although the nutritional factor has been preponderant, the other management factors have to be conducted in a balanced way since the market and institutional demands have 
been directed to characteristics of production volume and quality of the milk (Defante et al., 2019; Bánkuti et al., 2020).

\section{CONCLUSION}

It is concluded that aspects related to the nutritional management of the herd are the ones that mark the biggest difference between the cases analyzed, followed respectively by the factors of technical management and milking management. The typology of dairy systems that adopt greater attention to nutritional management practices is characterized by a greater production structure and greater productivity when compared to the typology of dairy systems that prioritize actions of technical management of the system and the management of milking management.

\section{CONFLICT OF INTEREST}

We certify that there is no conflict of interest with any financial, personal or other relationships with other people or organization related to the material discussed in the manuscript.

\section{ACKNOWLEDGEMENT}

The present study was funded by "Coordination for the Improvement of Higher Education Personnel of Brazil" (CAPES) and "Conselho Nacional de Desenvolvimento Científico e Tecnológico" (CNPq) in Brasilia, DF, Brazil, Projeto Universal 2016, Processo no. 405689/2016-0 and "Instituto Nacional de Ciência e Tecnologia para a Cadeia Produtiva do Leite" (INCT-LEITE/UEL-PR), Londrina, Paraná, Brasil", and "Fundação Araucaria", Curitiba-Paraná and Programa de Pós-graduação em Zootecnia (PPZ) - UEM.

\section{REFERENCES}

Bánkuti, F. I. \& M. M. Caldas. 2018. Geographical milk redistribution in Paraná State, Brazil : consequences of institutional and market changes. J. Rural Stud. 64, 63-72. https:// doi.org/10.1016/j.jrurstud.2018.10.004

Bánkuti, F. I., R. C. Prizon, J. C. Damasceno, M. M. De Brito, M. S. S. Pozza, \& P. G. L. Lima. 2020. Farmers' actions toward sustainability: a typology of dairy farms according to sustainability indicators. Animal. 14:S417-S423. https:// doi.org/10.1017/S1751731120000750

Barnes, A. P. \& L. Toma. 2012. A typology of dairy farmer perceptions towards climate change. Clim. Change. 112:507522. https://doi.org/10.1007/s10584-011-0226-2

Beber, C. L., A. F. R. Carpio, M. I. Almadani, \& L. Theuvsend. 2019. Dairy supply chain in Southern Brazil: barriers to competitiveness. Int. Food Agribus. Man. 22:651-673. https://doi.org/10.22434/IFAMR2018.0091

Bodenmüller Filho, A., J. C. Damasceno, I. T. S. Previdelli, R. G. Santana, C. E. C. O. Ramos, \& G. T. Santos. 2010. Tipologia de sistemas de produção baseada nas características do leite. Revista Brasileira de Zootecnia. 39:18321839. https://doi.org/10.1590/S1516-35982010000800028

Brito, M. M., F. I. Bánkuti, S. M. S. Bánkuti, G. T. Santos, J. C. Damasceno, \& E. M. Massuda. 2015. Horizontal arrangements and competitiveness of Small-Scale Dairy Farmers in Paraná, Brazil. Int. Food Agribus. Man. 18:1-18.
Casali, M., B. S. Mendonça, M. M. De Brito, M. G. R. Santos, P. G. L. Lima, T. T. S. Teixeira, J. C. Damasceno, \& F. I. Bánkuti. 2020. Information asymmetry among dairy producers in Paraná, Brazil. Semin. Cienc. Agrar. 41:295-306. https://doi.org/10.5433/1679-0359.2020v41n1p295

Defante, L., J. C. Damasceno, F. I. Bánkuti, \& C. E. C. O. Ramos. 2019. Typology of dairy production systems that meet Brazilian standards for milk quality. R. Bras. Zootec. 49:e20180023. https://doi.org/10.1590/rbz4820180023

FAO (Food and Agriculture Organization). 2019. FAOSTAT. Livestock primary. FAOSTAT, Roma, Italy. http://www. fao.org/faostat/en/\#home. [02 February 2020].

Fávero, L. P., P. Belfiore, F. L. Silva, \& B. L. Chan. 2009. Análise de Dados: Modelagem Multivariada Para Tomada de Decisões. $3^{\text {rd }}$ ed. Elsevier, Rio de Janeiro.

Foddy, W. 1994. Construction Questions for Interviews and Questionnnaries: Theory and Practice in Social. Cambridge University Press, Oxford. https://doi.org/10.1016/ S0031-9406(10)61110-8

Gelasakis, A. I., G. Rose, R. Giannakou, G. E. Valergakis, A. Theodoridis, P. Fortomaris, \& G. Arsenos. 2017. Typology and characteristics of dairy goat production systems in Greece. Livest. Sci. 197:22-29. https://doi.org/10.1016/j. livsci.2017.01.003

Guptill, A. 2009. Exploring the conventionalization of organic dairy: Trends and counter-trends in upstate New York. Agric. Hum. Values. 26:29-42. https://doi.org/10.1007/ s10460-008-9179-0

Hair Jr., J. F., W. C. Black, B. J. Babin, \& R. E. Anderson. 2009. Multivariate Data Analysis. $7^{\text {th }}$ ed. Prentice Hall, Saddle River.

IBGE (Instituto Brasileiro de Geografia e Estatística). 2015. Pesquisa da Pecuária Municipal - PPM. Instituto Brasileiro de Geografia e Estatística, Brasília. https://www.ibge.gov. br/estatisticas/economicas/agricultura-e-pecuaria/9107producao-da-pecuaria-municipal.html?=\&t=o-que-e. $\quad[03$ March 2020].

IBGE (Instituto Brasileiro de Geografia e Estatística). 2018. Censo Agropecuário 2017. Instituto Brasileiro de Geografia e Estatística, Brasília. https://censos.ibge.gov.br/ agro/2017/. [03 March 2020].

IBM (International Business Machine). 2009. Statistical Program for Social Sciences: SPSS. International Business Machine, New York. https://www.ibm.com/analytics/spssstatistics-software. [05 January 2020].

Koerich, G., J. C. Damasceno, F. I. Bánkuti, J. L. Parré, \& G. T. Santos. 2019. Influence of forage production area, concentrate supply, and workforce on productive results in milk production systems. Revista Brasileira de Zootecnia. 48:e20170177. https://doi.org/10.1590/rbz4820170177

Kostrowicki, J. 1977. Agricultural typology concept and method. Agric. Syst. 2:33-45. https://doi. org/10.1016/0308-521X(77)90015-4

Llanos, E., L. Astigarraga, \& V. Picasso. 2018. Energy and economic efficiency in grazing dairy systems under alternative intensification strategies. Eur. J. Agron. 92:133-140. https://doi.org/10.1016/j.eja.2017.10.010

Marnet, P. G., \& M. Komara. 2008. Management systems with extended milking intervals in ruminants: regulation of production and quality of milk. J. Anim. Sci. 86:47-56. https://doi.org/10.2527/jas.2007-0285

Mattos, C. A. C., \& A. C. Santana. 2014. As contribuições da pecuária leiteira para os agricultores familiares: um estudo no Sudeste do estado do Pará. Extensão Rural. 21:56-72. https://doi.org/10.5902/231817967780

Millogo, V., K. Svennersten Sjaunja, G. A. Ouédraogo, \& S. Agenäs. 2010. Raw milk hygiene at farms, processing units and local markets in Burkina Faso. Food Control. 21:10701074. https://doi.org/10.1016/j.foodcont.2009.12.029 
Notte, G., H. Cancela, M. Pedemonte, P. Chilibroste, W. Rossing, \& J. C. J. Groot. 2020. A multi-objective optimization model for dairy feeding management. Agric. Syst. 183:102854. https://doi.org/10.1016/j.agsy.2020.102854

Ponciano, P. F., \& J. D. Scalon. 2010. Spatial analysis of the dairy yield using a conditional autoregressive model. Semin. Cienc. Agrar. 31:487-496. https://doi. org/10.5433/1679-0359.2010v31n2p487

Rivas, J., J. Perea, E. Angón, C. Barba, M. Morantes, R. DiosPalomares, \& A. García. 2015. Diversity in the dry land mixed system and viability of dairy sheep farming. Ital. J. Anim. Sci. 14:179-186. https://doi.org/10.4081/ ijas.2015.3513

Roche,J.F.2006. The effect of nutritional management of the dairy cow on reproductive efficiency. Anim. Reprod. Sci. 96:282296. https://doi.org/10.1016/j.anireprosci.2006.08.007
Vanh Der Ploeg, J. D. 2010. Rural development reconsidered : building on comparative perspectives from China, Brazil and the European Union. Rivistia Di Economia Agraria. 65:163-190.

Walsh, S. W., E. J. Williams, \& A. C. O. Evans. 2011. A review of the causes of poor fertility in high milk producing dairy cows. Anim. Reprod. Sci. 123:127-138. https://doi. org/10.1016/j.anireprosci.2010.12.001

Wong, C. Y. \& G. Lim. 2020. A typology of agricultural production systems: Capability building trajectories of three Asian economies. Asia Pac. Viewp. 61:37-53. https://doi. org/10.1111/apv.12220

Zimpel, R., F. I. Bánkuti, M. A. Zambom, K. C. Kuwahara, \& S. M. S. Bánkuti. 2017. Characteristics of the dairy farmers who perform financial management in Paraná State, Brazil. Revista Brasileira de Zootecnia. 46:421-428. https:// doi.org/10.1590/s1806-92902017000500008 